[Letter]

\title{
Novel Three-component Zeolite Capsule Catalyst for Direct Synthesis of Isoparaffin
}

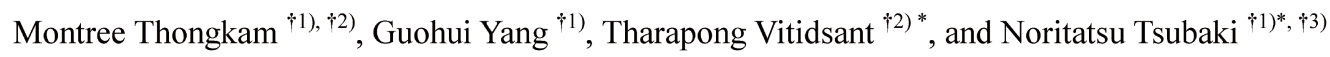 \\ ${ }^{* 1)}$ Dept. of Applied Chemistry, Graduate School of Engineering, University of Toyama, \\ Gofuku 3190, Toyama 930-8555, JAPAN \\ ${ }^{\dagger 2}$ Dept. of Chemical Technology, Faculty of Science, Chulalongkorn University, \\ Bangkok 10330, THAILAND \\ ${ }^{\dagger 3}$ JST, CREST, Sanbancho 5, Chiyoda-ku, Tokyo 102-0075, JAPAN
}

(Received March 23, 2009)

One zeolite capsule catalyst with core $\left(\mathrm{Co} / \mathrm{Al}_{2} \mathrm{O}_{3}\right) /$ shell(H-beta membrane) structure was prepared and used for isoparaffin direct synthesis via FTS reaction. Based on this core/shell zeolite capsule catalyst, a novel palladium painted zeolite capsule catalyst with three-component core $\left(\mathrm{Co} / \mathrm{Al}_{2} \mathrm{O}_{3}\right) /$ shell $(\mathrm{H}$-beta membrane)/paint (Pd) structure was designed. In the isoparaffin synthesis on this three-component zeolite capsule catalyst, the olefins effused from the zeolite capsule catalyst were in-situ hydrogenated effectively, mostly converted to isoparaffin.

Keywords: Isoparaffin, Zeolite, Microencapsulation, Three-component structure, Hydrogenation

\section{Introduction}

Recently, more attention has been focused on the production of light isoparaffin via FTS reaction because of its wide foreground as synthetic gasoline alkylate. Zeolite was the effective catalyst for cracking and isomerization reaction ${ }^{1)}$. The physically mixed catalyst of conventional FTS catalyst and zeolite can not decompose the heavy hydrocarbons in the final FTS products completely $^{2)}$. Previous work of our group had represented a novel catalyst with a core/shell structure ${ }^{3)}$. Herein, we presented a catalyst with a new core $\left(\mathrm{Co} / \mathrm{Al}_{2} \mathrm{O}_{3}\right)$ and new shell (H-beta membrane). And then, a three-component zeolite capsule catalyst with the core $\left(\mathrm{Co} / \mathrm{Al}_{2} \mathrm{O}_{3}\right) /$ shell (H-beta membrane)/paint $(\mathrm{Pd})$ structure was prepared by loading palladium on the H-Beta zeolite shell. In the synthesis reaction, the selectivity of light isoparaffin was increased effectively using only this single three-component zeolite capsule catalyst.

\footnotetext{
イソパラフィンの直接合成用三成分ゼオライトカプセル型触媒 Montree Thongkam ${ }^{\dagger 1,2)}$, 楊 國輝 ${ }^{\dagger 1)}$, Tharapong Vitidsant ${ }^{\dagger 2}{ }^{*}$, 椿 範立 ${ }^{11,3)^{*}}$

†1) 富山大学工学部, 930-8555 富山市五福 3190

†3) 科学技術振興機構 CREST, 102-0075 東京都千代田区三番町 5

* Corresponding author,E-mail: tsubaki@eng.u-toyama.ac.jp;

Tharapong.V@Chula.ac.th
}

\section{Experimental}

The conventional FTS catalyst $5 \mathrm{wt} \% \mathrm{Co} / \mathrm{Al}_{2} \mathrm{O}_{3}$ was prepared by the incipient wetness impregnation of $\gamma-\mathrm{Al}_{2} \mathrm{O}_{3} \quad$ (JRC-ALO-6, 0.35-0.85 mm) with $\mathrm{Co}\left(\mathrm{NO}_{3}\right)_{2} \cdot 6 \mathrm{H}_{2} \mathrm{O}$ solution. The zeolite membrane synthesis recipe for $\mathrm{H}$-Beta zeolite capsule catalyst preparation was $48.24 \mathrm{SiO}_{2}: 17.40 \mathrm{TEAOH}: 1.0 \mathrm{Al}_{2} \mathrm{O}_{3}$ : $519.3 \mathrm{H}_{2} \mathrm{O}$. Tetraethylammonium hydroxide (TEAOH) was the template. Hydrothermal synthesis was performed on the $\mathrm{Co} / \mathrm{Al}_{2} \mathrm{O}_{3}$ at $428 \mathrm{~K}$ with rotation rate of $2 \mathrm{rpm}$ for $24 \mathrm{~h}$. The final zeolite capsule catalyst after the calcination at $823 \mathrm{~K}$ for $8 \mathrm{~h}$ was named $\mathrm{Co} / \mathrm{Al}_{2} \mathrm{O}_{3}-\mathrm{B}$. The zeolite capsule catalyst without calcination was used to prepare the three-component zeolite capsule catalyst by incipient wetness impregnation method with dinitrodiammine palladium aqueous solution. The three-component zeolite capsule catalyst with $2.5 \mathrm{wt} \%$ $\mathrm{Pd}$ loading, named $\mathrm{Co} / \mathrm{Al}_{2} \mathrm{O}_{3}-\mathrm{Pd} / \mathrm{B}$, was obtained after calcination at $823 \mathrm{~K}$ for $8 \mathrm{~h}$.

\section{Results and Discussion}

The catalysts of conventional FTS catalyst $\mathrm{Co} / \mathrm{Al}_{2} \mathrm{O}_{3}$, zeolite capsule catalyst $\mathrm{Co} / \mathrm{Al}_{2} \mathrm{O}_{3}$-B and three-component zeolite capsule catalyst had been characterized by XRD 
(Rigaku, RINT 2400), SEM (JEOL, JSM-6360LV) and EDS (JEOL, JED-2300) analysis. The XRD analysis of zeolite capsule catalyst $\mathrm{Co} / \mathrm{Al}_{2} \mathrm{O}_{3}-\mathrm{Pd} / \mathrm{B}$ identified the emergence of $\mathrm{H}$-Beta zeolite on the core catalyst of $\mathrm{Co} / \mathrm{Al}_{2} \mathrm{O}_{3}$.

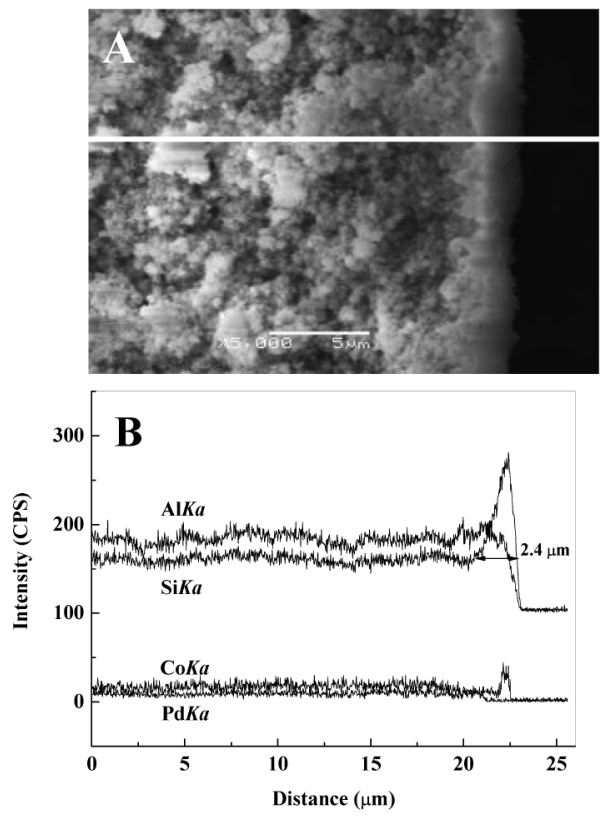

Fig. 1 (A) Cross Section SEM Image and (B) EDS Line Analysis of $\mathrm{Co} / \mathrm{Al}_{2} \mathrm{O}_{3}-\mathrm{Pd} / \mathrm{B}$

Figures 1A, 1B shown the cross-sectional SEM image of $\mathrm{Co} / \mathrm{Al}_{2} \mathrm{O}_{3}-\mathrm{Pd} / \mathrm{B}$ and its EDS line analysis. In Fig. 1A, a compact beta zeolite shell coated on the $\mathrm{Co} / \mathrm{Al}_{2} \mathrm{O}_{3}$ surface can be observed clearly, and there was no crack or pinhole on the zeolite shell. The EDS line analysis in Fig. 1B showed that the radial distribution of SiKa increased suddenly while the AlKa dropped slightly at the interface of substrate with zeolite shell, indicating the phase change from $\mathrm{Co} / \mathrm{Al}_{2} \mathrm{O}_{3}$ to $\mathrm{H}$-beta, proving the complete coverage of H-beta zeolite membrane onto $\mathrm{Co} / \mathrm{Al}_{2} \mathrm{O}_{3}$ core.

To ascertain the performance of H-Beta zeolite capsule catalyst $\mathrm{Co} / \mathrm{Al}_{2} \mathrm{O}_{3}-\mathrm{B}$ and three-component zeolite capsule catalyst $\mathrm{Co} / \mathrm{Al}_{2} \mathrm{O}_{3}-\mathrm{Pd} / \mathrm{B}$, the conventional FTS catalyst of $10 \mathrm{wt} \% \mathrm{Co} / \mathrm{Al}_{2} \mathrm{O}_{3}$ was also tested. Table 1 presented the reaction performance of these catalysts. Zeolite capsule catalyst $\mathrm{Co} / \mathrm{Al}_{2} \mathrm{O}_{3}-\mathrm{B}$ gave a lower $\mathrm{CO}$ conversion than that of $\mathrm{Co} / \mathrm{Al}_{2} \mathrm{O}_{3}$, probably because of the partial coverage of Co active sites on the core by zeolite crystal during the hydrothermal synthesis process. For
$\mathrm{Co} / \mathrm{Al}_{2} \mathrm{O}_{3}-\mathrm{Pd} / \mathrm{B}$, the palladium loaded on the surface of $\mathrm{Co} / \mathrm{Al}_{2} \mathrm{O}_{3}-\mathrm{B}$ might partly decrease the syngas diffusion rate while passing through the zeolite shell. As a result, $\mathrm{Co} / \mathrm{Al}_{2} \mathrm{O}_{3}-\mathrm{Pd} / \mathrm{B}$ exhibited the lowest catalyst activity of $32.35 \%$ than other catalysts.

Table 1 Reaction Performances of Zeolite Capsule Catalyst, Three-component Zeolite Capsule Catalyst ${ }^{\text {a) }}$

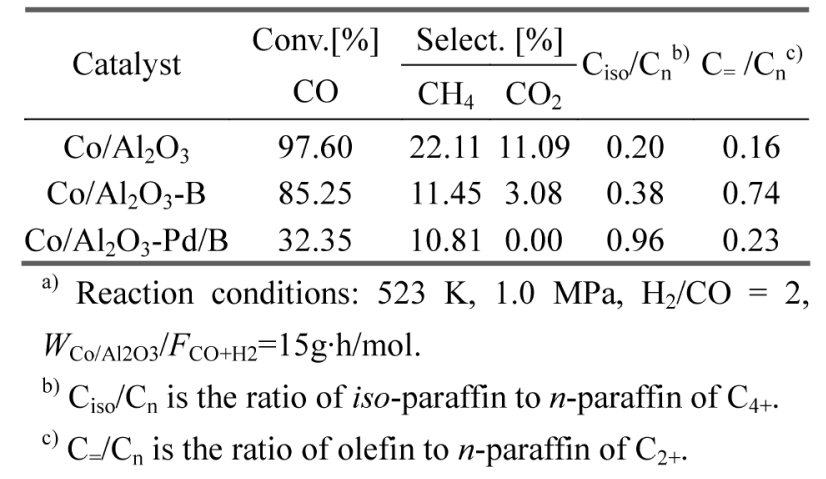

For the isoparaffin synthesis, $\mathrm{Co} / \mathrm{Al}_{2} \mathrm{O}_{3}$ gave the lowest $\mathrm{C}_{\text {iso }} / \mathrm{C}_{\mathrm{n}}$ ratio of 0.20 , although with the highest catalytic activity. For $\mathrm{Co} / \mathrm{Al}_{2} \mathrm{O}_{3}-\mathrm{B}$, the $\mathrm{C}_{\text {iso }} / \mathrm{C}_{\mathrm{n}}$ ratio was 0.38 , proving its effectiveness for isoparaffin direct synthesis with the spatial consecutive reaction model. However, the selectivity of olefins increased along with the production of isoparafin undergoing the cracking reaction. Based on the hydrogenation of olefins by the palladium loaded on the zeolite shell, three-component zeolite capsule catalyst $\mathrm{Co} / \mathrm{Al}_{2} \mathrm{O}_{3}-\mathrm{Pd} / \mathrm{B}$ with the core/shell/paint structure exhibited the highest isoparaffin selectivity of 0.96. All the reactions, FTS, cracking, isomerization and hydrogenation can be accomplished simultaneously only using this single catalyst. Three-component H-beta zeolite capsule catalyst with core/shell/paint structure explored a new way for simple synthesis of multiple step reactions.

\section{References}

1) Feller, A., Guzman, A., Zuazo, I., Lercher, J. A., J. Catal., 224, 80 (2004).

2) Tsubaki, N., Yoneyama, Y., Michiki, K., Fujimoto, K., Catal. Commun., 4, 108(2003).

3) He, J., Liu, Z., Yoneyama, Y., Nishiyama, N., Tsubaki, N., Chem. Eur. J., 12, 8296 (2006). 